\title{
INCIDENCE OF GASTRIC AND DUODENAL ULCER IN THE ROYAL AIR FORCE IN 1955
}

\author{
BY
}

\author{
J. H. BARON \\ Middlesex Hospital, London \\ AND \\ R. VAUGHAN JONES \\ St. Thomas's Hospital, London
}

In a previous paper (Baron and Vaughan Jones, 1958) we discussed the difficulties of estimating the prevalence of gastric and duodenal ulcer. We concluded, as had Doll (1952), that a population survey was the method of choice, and we studied the whole British Army of 1955. Some of our findings were sufficiently different from those of British and other civilians for us to seek another large population. In 1955 there were 245,320 men (officers and other ranks) in the Royal Air Force (R.A.F.). We have analysed the morbidity from peptic ulcer diagnosed that year for the first time.

\section{METHOD}

In 1955, diagnoses of gastric, duodenal, or peptic ulceration were made in 909 R.A.F. personnel. The medical documents could not be traced in three cases, but each of the remaining 906 ( 99.7 per cent.) was examined. A total of 347 were excluded: the initial diagnosis had been made before 1955 for 328 patients, 13 patients were female, and there had been errors of coding for six patients.

The remaining 559 men were admitted to hospital in 1955 for the first time with a diagnosis of peptic ulcer. In 126 patients the diagnosis was presumptive, in 46 because they had not had a barium meal, and in eighty because the results were negative.

The remaining 433 patients were considered to have had proven ulcers according to the criteria used in the previous paper:

(1) 366 duodenal and 24 gastric ulcers were shown by barium meal to the satisfaction of the radiologist concerned, as were two ulcers of which the site was not stated. One patient had both a gastric and a duodenal ulcer.

(2) Thirty duodenal, seven gastric, and one ulcer with site not specified were found at laparotomy to have perforated.
(3) One duodenal, one gastric, and one ulcer of unspecified site were found at laparotomy for haematemesis.

(4) Three duodenal and one gastric ulcer were found at elective gastric surgery.

(5) Neither gastroscopy nor autopsy contributed to this series.

In some cases the diagnosis was established by more than one method in the course of the year, and therefore the total of the above group, 438 , is more than the number of patients, 433.

The one patient with an ulcer in both his stomach and in his duodenum, and the four patients with ulcers the site of which was not stated ("peptic", "pyloric") are omitted from further consideration. We have analysed the remaining 428 patients by age at diagnosis, by frequency of presentation with perforation, and by attack rate, as calculated from average figures for male R.A.F. personnel in 1955.

\section{RESULTS}

Table I (opposite) shows the number of ulcers diagnosed, the ratio of duodenal to gastric ulcers, and the attack rates per 1,000 men at different ages. The number and proportion of ulcers which presented by perforation are shown in Table II (opposite).

\section{INCIDENCE OF DUODENAL ULCER}

The overall incidence of newly diagnosed duodenal ulcers was 1.6 per 1,000 men. Taking the 19-year-olds as the most representative of the same age group of the whole male population of the United Kingdom, there were 35 duodenal ulcers in 38,003 men of this age, a rate of 0.92 per 1,000 men.

The attack rate was lowest in $1 \cdot 1$ per 1,000 men in the 16-19 year age group and rose to a maximum of 3.4 per 1,000 men in the 35-39 year age group. The overall incidence was similar to that in the 
TABLE I

NUMBER OF CASES, DUODENAL/GASTRIC RATIO, AND ATTACK RATES, BY AGE

\begin{tabular}{|c|c|c|c|c|c|c|c|}
\hline \multirow{2}{*}{ Age (yrs) } & \multirow{2}{*}{ No. of Men } & \multicolumn{2}{|c|}{ No. of Ulcers Diagnosed } & \multirow{2}{*}{$\begin{array}{c}\text { Ratio } \\
\text { Duodenal : Gastric }\end{array}$} & \multicolumn{3}{|c|}{ Annual Incidence per 1,000 Men } \\
\hline & & Duodenal & Gastric & & $\begin{array}{l}\text { Duodenal } \\
\text { Ulcer }\end{array}$ & $\begin{array}{l}\text { Gastric } \\
\text { Ulcer }\end{array}$ & Both \\
\hline $\begin{array}{c}16-19 \\
20-24 \\
25-29 \\
30-34 \\
35-39 \\
40-44 \\
45+\end{array}$ & $\begin{array}{r}57,587 \\
120,592 \\
22,426 \\
16,342 \\
13,353 \\
8,859 \\
6,161\end{array}$ & $\begin{array}{r}62 \\
160 \\
46 \\
40 \\
45 \\
29 \\
14\end{array}$ & $\begin{array}{r}3 \\
13 \\
4 \\
8 \\
0 \\
2 \\
2\end{array}$ & $\begin{array}{r}20 \cdot 7: 1 \\
12 \cdot 3: 1 \\
11 \cdot 5: 1 \\
5 \cdot 0: 1 \\
14 \cdot 5: 1 \\
7 \cdot 0: 1\end{array}$ & $\begin{array}{l}1 \cdot 1 \\
1 \cdot 3 \\
2 \cdot 1 \\
2 \cdot 4 \\
3 \cdot 4 \\
3 \cdot 3 \\
2 \cdot 3\end{array}$ & $\begin{array}{l}0.05 \\
0.1 \\
0.2 \\
0.5 \\
0.0 \\
0.2 \\
0.3\end{array}$ & $\begin{array}{l}1.1 \\
1.4 \\
2.2 \\
2.9 \\
3.4 \\
3.5 \\
2.6\end{array}$ \\
\hline All Ages ... & 245,320 & 396 ; & 32 & $12 \cdot 4: 1$ & $1 \cdot 6$ & $0 \cdot 1$ & $1 \cdot 7$ \\
\hline
\end{tabular}

TABLE II

NUMBER AND PERCENTAGE OF ULCERS WHICH PRESENTED BY PERFORATION, BY AGE

\begin{tabular}{|c|c|c|c|c|c|c|}
\hline \multirow{3}{*}{$\begin{array}{c}\text { Age } \\
\text { (yrs) }\end{array}$} & \multicolumn{3}{|c|}{ Duodenal } & \multicolumn{3}{|c|}{ Gastric } \\
\hline & \multirow{2}{*}{$\begin{array}{c}\text { Total } \\
\text { Diagnosed }\end{array}$} & \multicolumn{2}{|c|}{ Perforated } & \multirow{2}{*}{$\begin{array}{c}\text { Total } \\
\text { Diagnosed }\end{array}$} & \multicolumn{2}{|c|}{ Perforated } \\
\hline & & Number & $\begin{array}{l}\text { Per } \\
\text { cent. }\end{array}$ & & Number & $\begin{array}{l}\text { Per } \\
\text { cent. }\end{array}$ \\
\hline $\begin{array}{c}16-19 \\
20-24 \\
25-29 \\
30-34 \\
35-39 \\
40-44 \\
45+\end{array}$ & $\begin{array}{r}62 \\
160 \\
46 \\
40 \\
45 \\
29 \\
14\end{array}$ & $\begin{array}{r}2 \\
14 \\
5 \\
4 \\
2 \\
3 \\
0\end{array}$ & $\begin{array}{r}3 \\
9 \\
11 \\
10 \\
4 \\
10 \\
-\end{array}$ & $\begin{array}{r}3 \\
13 \\
4 \\
8 \\
0 \\
2 \\
2\end{array}$ & $\begin{array}{l}1 \\
2 \\
1 \\
2 \\
0 \\
0 \\
1\end{array}$ & $\begin{array}{l}33 \\
15 \\
25 \\
25 \\
\frac{7}{50}\end{array}$ \\
\hline$\overline{\text { All Ages }}$ & 396 & 30 & 8 & 32 & 7 & 22 \\
\hline
\end{tabular}

British Army, and the distribution was similar to both the Army and the civilian series. As in the Army, the peak incidence was less than one-tenth of the civilian ulcer incidence.

\section{INCIDENCE OF GASTRIC ULCER}

The overall incidence of gastric ulcer was $0 \cdot 1$ per 1,000 men. There was only one gastric ulcer in 38,003 men aged 19 , an attack rate of 0.03 per 1,000 men. In all there were only 32 gastric ulcers to analyse, but their distribution and minimum and maximum age incidences, were similar to the Army figures, while the overall incidence was about half that in the Army.

\section{Duodenal/Gastric Ratio}

Table I shows that the ratio of duodenal to gastric ulcer in all age groups was $12 \cdot 4: 1$. This figure is higher than that in the British Army in 1955 $(7 \cdot 65: 1)$ and that found in $1942(4 \cdot 6: 1)$ (Tidy, 1943), and is also higher than that in the U.S. Army in $1937-41(5: 1)$ or 1942-5 $(10: 1)$ (Hamilton, Sullivan, and Palmer, 1952).

The ratio under 45 years of age in the present series is $12.7: 1$ compared with $8 \cdot 2: 1$ in the British Army. In civilian out- and in-patients the ratio in a London series was $5 \cdot 5: 1$ (Jones and Pollak, 1945) and in Glasgow 13.2:1 (Jamieson, Smith, and Scott, 1949). In the only other population surveys, this ratio was $2 \cdot 3: 1$ in men under 45 in London (Doll, Jones, and Buckatzsch, 1951), 2.3 : 1 in men under 50 in Drammen, Norway (Knutsen and Selvaag, 1947), and 4.05:1 in 1948 in men under 50 in Denmark (Alsted, 1953).

\section{Perforated Ulcers}

Table II shows that 8 per cent. of duodenal ulcers and 22 per cent. of gastric ulcers presented with perforation, figures similar to those found in the Army.

\section{ARMY/AIr Force DifFerences}

The only major difference in the incidence of peptic ulcer between the Army and the R.A.F. is that there is a significantly lower incidence of gastric ulcer in the R.A.F. with, therefore, a higher duodenal/gastric ulcer ratio. We do not believe that there are different standards of diagnosis in these two Services, so that this lower incidence of gastric ulcer must be related to differences either in the environment or in the individuals recruited.

Environmental factors could include the quantity and quality of food, alcohol, and tobacco, the nature of employment and its hazards, and the areas of the military establishments. These factors are difficult to measure, and personal observations have not suggested any gross differences.

On the other hand, there were in 1955 undoubted social and educational differences in the composition of the Army and Air Force, related to their different fighting functions and equipment. Many clinicians have long suspected that there are social differences in peptic ulcer incidence, and between the types of ulcer. These clinical impressions are supported by the Registrar General's studies on Occupational Mortality. For example, in 1949-53, the Standardized Mortality Ratio of ulcers of the stomach 
and duodenum increased from Social Class I (Professional) to V (Unskilled). This social gradient is very much steeper for gastric than for duodenal ulcer (Logan, 1959).

\section{SUMMARY}

All in-patient case summaries of peptic, gastric, and duodenal ulcer patients in the Royal Air Force in 1955 were sought, and 99.7 per cent. were found, examined, and assessed. In 1955, 366 duodenal and 32 gastric ulcers were diagnosed for the first time in approximately 250,000 male personnel of the R.A.F. The overall incidence rates of duodenal and gastric ulcers were $1 \cdot 6$ and $0 \cdot 1$ per 1,000 men respectively. The data were analysed by age, and attack rates were estimated in the various age groups for proven gastric and duodenal ulceration, together with the proportions presenting with perforation. The results are in general similar to those previously found in the British Army, but the incidence of gastric ulcer is significantly less, and this difference is discussed.

We are indebted to Air Commodore J. S. Wilson and Group Captain R J. A. Morris of the Department of. Hygiene and Research, the Air Ministry, for their help and for making available to us the medical records of patients with ulcer in the Royal Air Force. We wish to thank the Director-General of Medical Services, the Royal Air Force, for permission to publish.

\section{REFERENCES}

Alsted, G. (1953). "The Incidence of Peptic Ulcer in Denmark". Danish Science Press, Copenhagen.

Baron, J. H., and Jones, R. Vaughan (1958). Brit. J. prev. soc. Med.,

12, 71 . (1952). In “Modern Trends in Gastro-Enterology", ed. F. Avery Jones, p. 361. Butterworth, London.

, Jones, F. A verý, and Buckatzsch, M. M. (1951). Spec. Rep. Ser. med. res. Coun., No. 276. H.M.S.O., Lond.

Hamilton, E. L., Sullivan, B. H., and Palmer, E. D. (1952). U.S armed Forces med. J., 3, 831 .

Jamieson, R. A., Smith, W. E., and Scott, L. D. W. (1949). Brit. med. J., 1, 298 .

J., 1, 298.
Jones, F. Avery, and Pollak, H. (1945). Ibid., 1, 797.

Knutsen, B., and Selvaag, O. (1947). Acta med. scand., Suppl. 196, p. 341 .

Logan, W. P. D. (1959). Proc. roy. Soc. Med., 52, 463.

Tidy, H. (1943). Brit. med. J., $2,473$. 